\title{
Diskrétní simulace v konceptu Industry 4.0
}

\author{
Miroslav Malaga ${ }^{1}$, Zdeněk Ulrych ${ }^{1}$ \\ 1 Západočeská univerzita v PIzni, Fakulta strojní, Katedra průmyslového inženýrství a \\ managementu \\ Univerzitní 8, Plzeň, 306 14, Česká republika \\ malaga@kpv.zcu.cz \\ ulrychz@kpv.zcu.cz
}

\begin{abstract}
Anotace: Příspěvek je rešerší článků, zveřejněných hlavně $v$ databázích Web of Science (WoS) a Scopus, zaměřených na 5 hlavních témat, a to:

1. Vliv detailnosti modelu na výsledky simulace

2. Optimalizace plánování výroby $s$ ohledem na využití energie a prírodních zdrojů

3. Plánování výroby pomocí simulačního modelu v kontextu Industry 4.0 resp. 5.0

4. Metodika prístupu k tvorbě simulačního modelu v kontextu Industry 4.0 a využití simulačních modelů
\end{abstract}

5. Koncept Industry 5.0

Tato témata jsou zvolena sohledem na možný budoucí výzkum a nutností zorientovat se vaktuálním vývoji konceptu Industry 4.0 ve spojitosti se simulacemi, plánováním a optimalizací. Koncept Industry 5.0 je zvolen kvůli možnému vysledování nových trendů. Databáze Web of Science a Scopus byly pro vyhledávání článků pro rešerši zvoleny na základě uznávání článku v těchto databázích českými univerzitami.

\section{Vliv detailnosti modelu na výsledky simulace}

Při tvorbě podkladů pro simulaci je potřeba důkladně zanalyzovat prostředí/systém na základě kterého se vytvárí model a následně daný model se i vytvoří. To je časově velmi náročné jak pro odborníka, který má model vytvořit, tak pro stranu uživatele/vlastníka systému, pro který se model vytváŕí. Důvodem je potřeba důkladně vysvětlit, jak daný systém funguje a často to $\mathrm{i}$ zjistit, protože ne vždy uživatel/vlastník systému rozumí do všech potřebných detailu a úrovní (jde především o vyloučení velkého zkreslení, nebo zjednodušování, které by mělo fatální dopady důvěryhodnost a reálnost modelu s ohledem na cíle simulace). Nad daným modelem se následně provádí simulace. Základní myšlenka tohoto tématu je zjistit, jaký je přesně vztah mezi detailností/přesností modelu a výsledky simulace. Je možné, že prì rozumně vytvořeném modelu se výsledky simulace nebudou tak zásadně lišit od modelu který by byl zpracovaný do nejmenšího detailu. Tím by mohlo dojít ke značné časové, i finanční úspoře. Zde se dá očekávat, že se to také projeví zkrácením času běhu simulace a rychlejšímu dodání výsledků, aniž by došlo $\mathrm{k}$ neakceptovatelnému zkreslení. Z pohledu tohoto tématu nebyly 
nalezený adekvátní články, které by řešily dopady detailnosti modelu na výsledky simulace

Pro vyjádření vztahu detailnosti modelu a výsledků simulace je standardně využíván obrázek, viz Obrázek 1 , např. v přednáškách pro simulaci pana Ing. Michala Dordy Ph.D. [1], nebo disertační práci Ing. et Ing. Pavla Šenkýře [2] kde je graf také ukázán s odkazem na původní zdroj JONES, M. The contradictions of business process reengineering. In: Examining Business process reengineering: Current Perspectives and Research Directions. Další odborníci používají obdobný graf bez odkazu (citace), jako např. Ing. V. Glombíková, PhD. Ve svých přednáškách [3].

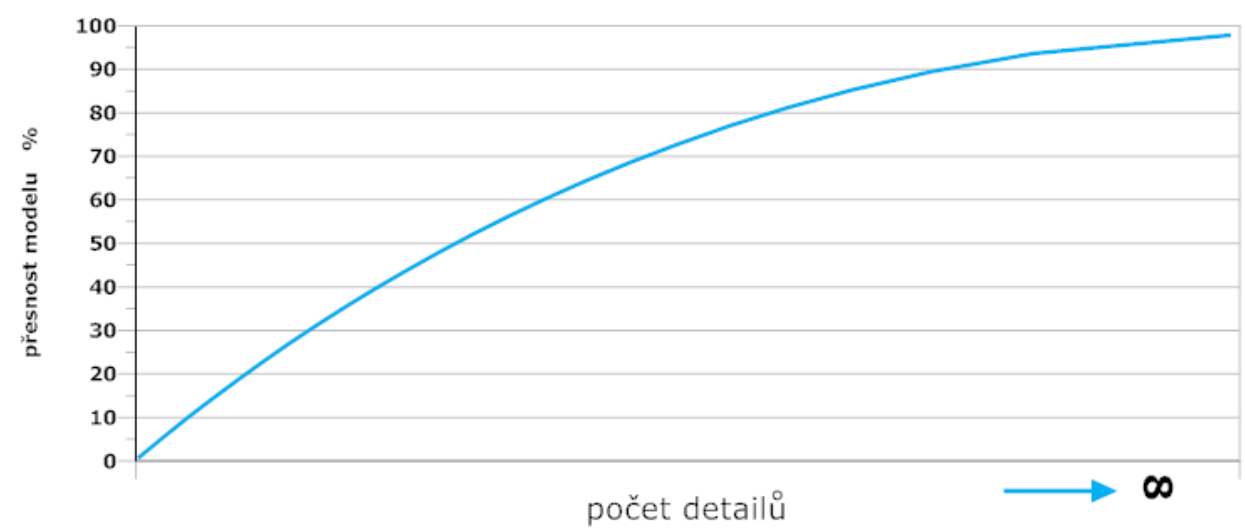

Obrázek 1 - Vliv míry abstrakce na přesnost modelu [2]

$\checkmark$ článku "Simulation Modeling of Assembly Processes for Digital Manufacturing" [4] autoři uvádějí, že důležitým problémem, který se objevuje při vytváření simulačních modelů je, jak přesně by měl simulační model odrážet skutečné výrobní systémy. Autoři v simulaci montážních procesů používají model, který je připraven pomocí softwaru Tecnomatix Plant Simulation a navrhují postup pro sestavení a analýzu simulačního modelu. Nezaměřují se ale prímo na vliv detailnosti modelu na výsledky simulace a kvantifikování tohoto vlivu.

\section{Optimalizace plánování (nebo plánování) výroby s ohledem na využití energií a prírodních zdrojủ (zelené plánování výroby)}

$\checkmark$ dnešní době je, čím dál tím větší důraz, kladený na život jedince s co nejmenším dopadem pro naši zemi. Je zde viditelná snaha redukovat použíaání plastů a dalších materiálů, který může být škodlivý pro životní prostředí. Čím dál tím větší část populace přemýšlí i o minimalizaci zbytečného přemist'ování jak osob, tak služeb, materiálu, nebo výrobků $v$ rámci naší planety. Toto už není jen otázka jedinců, ale začínají takto přemýšlet už i výrobní společnosti, nebo společnosti nabízející služby. Toto myšlení pak má dopady i na návrh produktů (design, materiály, ...) a hlavně na způsob výroby. Cena, resp. finanční náklady, přestávají být tím nejdůležitějším faktorem při volbě způsobu výroby, využívaných strojů apod., 
ale už se rozhoduje i podle potřebných energií a jejich množství a prírodních zdrojů - a to bez ohledu na finanční výhodnost, popř. jen s rozumným priihlédnutím $\mathrm{k}$ poměru náklady/energie a prírodní zdroje. Je tedy prihlíženo nejen $\mathrm{k}$ tomu, jestli jsme schopni produkt vyrobit levněji/dráž, ale začíná se přihližet, jestli vyrobím produkt levněji, ale s větším „plýtváním“ energií, popř. prírodních zdrojů, nebo dráž ale s menším „plýtváním“ energií, popř. prírodních zdrojů.

Jedním z přístupů $\mathrm{k}$ minimalizaci emise uhlíků je snížení spotřeby energie v konkrétním obráběcím systému. Autoři navrhují integrační model založený na nelineárním plánování procesů a implementaci takové metody, která povede ke snížení energetické spotřeby obráběcího systému. Využívají model založený na Therbligu [5]. Jinými přístupy pak je minimalizace emisí uhlíků řešením problému kapacitního vícenásobného určování velikosti dávky u neidentických paralelních strojů, kdy je cílem uspokojit poptávku po různých položkách $v$ plánovacím horizontu $s$ cílem minimalizovat náklady aniž by došlo k omezení kapacity a nárůstu emisí uhlíku s využitím Lagrangianovy relaxaxe a metodou generování sloupců pro zlepšení dolních a horních hranic nad lineární programovací relaxací [6]. Podobný problém řeší i jiní autoři, kteří představují matematickou formulaci, řešící problém zelené výroby na paralelních strojích s ohledem na spotřebu energie a výrobní čas. Vzhledem $\mathrm{k}$ vysoké výpočetní složitosti navrhovaného modelu vyvinuli heuristický algoritmus pro získání přesné Paretovy hranice těchto dvou cílů $\mathrm{s}$ polynomiální složitostí [7]. Jako jiný zpưsob řešení je možnost využití hybridního algoritmu roje $s$ diskrétními částicemi na základě reálných dat shromážděných od farmaceutického podniku. Model plánování výroby je postavený na analýze spotřeby energie různých jednotek a zařízení a experimentální výsledky ukázaly, že emise uhlíku $v$ podniku mohou být sníženy v průměru o $6,77 \%$, nebo Ize snížit emise CO2 o 610,2 tun ročně [8]. Dalším možným prístupem je i zlepšení zelené produktivity (GP) kde základním mechanismem algoritmu je realizace cyklu zlepšování procesů, který měří výkon GP pomocí sběru obráběcích dat, kvantifikuje tento výkon kategorickým znázorněním a předpovídá výkon pomocí predikčních modelů. [9]

Jako jiná možnost minimalizace spotřeby energie je studován model nazvaný ultra-flexibilní job shop (UFJS). V UFJS Ize pořadí operací mezi úlohami změnit $v$ rámci určitých omezení. Pro formulaci tohoto energeticky účinného plánování byl vyvinut smíšený celočíselně-lineárně naprogramovaný model. Pro řešení velkých problémů pak následně autoři navrhli a implementovali genetický algoritmus. [10]

Autoři článku „TOWARDS INDUSTRY 4.0 IN CORPORATE ENERGY MANAGEMENT" [11] uvádějí, že je na trhu nabízeno více než 120 softwarových systémů, které ale podle jejich analýzy kvůli své hrubé zrnitosti Ize použít výlučně pro funkci monitorování a podávání zpráv. Plánování a řízení není podporováno. Vyvinuli tedy systém řízení energie $s$ možností sběru údajů o spotřebě energie na úrovni výrobních zařízení na základě 
datových listů výrobců zařízení a modulární a samoorganizovaný komunikační systém (jako kombinace hardwaru a softwaru), který „čte“ interní data elektrické energie $z$ výrobních zařízení v reálném čase, popř. měří průtok tekutin nebo plynů pomocí senzorů a zajišt'uje řízení energie v reálném čase.

Zajímavou možností minimalizace nákladů na energii ( $v$ tomto př́padě jde opravdu o náklady, ne o minimalizaci uhlíkové stopy, nebo spotřeby) je optimalizace variant produktů. Autoři vidí vazbu mezi rozmanitostí výroby a spotřebou energie. Vyvinuli model založený na simulaci, který zkoumá účinky rozmanitosti výroby na spotřebu energie (elektřina, stlačený vzduch, plyn). Model byl implementován $v$ simulačním prostředí diskrétních událostí a ověřen $v$ prípadové studii $v$ kovoprůmyslu. Výsledky ukazují, že efektivní správa variant umožňuje zlepšení energetické účinnosti. [12]

\section{Plánování výroby pomocí simulačního modelu v kontextu Industry 4.0}

Rozumně navržený a vytvořený model a nad ním následně běžící simulace $s$ vhodnými parametry je využitelná jako nástroj pro výběr vhodného toku výrobků výrobním procesem. Jinými slovy, Ize využít model a nad ním běžící simulaci pro plánování výroby. $S$ tím, jak se vyvijí prístup k výrobě a přichází stále nové trendy ve výrobě, je potřeba adekvátně príizpůsobovat způsoby plánování. Aktuálně takovým novým prístupem, resp. paradigmatem je koncept Industry 4.0, který staví na přesunu stále opakujících se činností, nebo jednoduchých činností od člověka ke stroji a komunikaci jak mezi lidmi, lidmi a stroji, tak samotnými stroji. Jako vhodné využití by tedy mohlo být využití simulací pro plánování výroby v podniku stavějícím na konceptu Industry 4.0 a věnujícímu se převážně malosériové výroby, kdy je potřeba pro nový produkt/nebo novou sérii řešit přenastavení výrobních strojů, vhodnou zaměnitelnost, a řešit stavy, kdy dojde $\mathrm{k}$ souběhu výroby několika druhů výrobků, popř. jeden druh ve výrobě dobíhá a souběžně s tím se nový už taky má vyrábět. Vize je pak taková, že materiál může při výrobě procházet několika cestami, zaměnitelné stroje hlásí svưj stav (nastavení, využití, ...) a pak Ize plánovat výrobu jak pro nový výrobek, tak teoreticky i pro každý jeden kus prì vstupu do systému podle stavu na celé lince. Pro to je ale potřeba upravit některý ze stávajících způsobu rozvrhování výroby, nebo vytvořit metodiku zcela novou. S plánováním výroby má spojitost i prediktivní údržba, která do plánování může zanášet možné odstávky strojů apod.

Stálým trendem pro sběr dat (pro simulace), nebo jejich vizualizaci, je využívání digitálních dvojčat, která se doplňují o moderní možnosti jako např. strojové učení. Tato digitální dvojčata jsou využívána pro vývoj inteligentních algoritmů pro autonomní řízení a další případy zahrnující optimalizaci, mentální modely a systémy podpory rozhodování [13]. Digitální dvojče umožňuje pro výrobní proces propojení produkčního systému $\mathrm{s}$ jeho digitálním ekvivalentem. Aby byla zajištěna maximální shoda kybernetického procesu $\mathrm{s}$ jeho skutečným modelem, musí být dle autorů provedeno 
multimodální získávání a hodnocení dat [14]. F. Jaensch a kol. [15] představují možnost rozšíření digitálních dvojčat o možnost strojového učení modelů založených na datech až po učení logiky řízení složitých systémů. Ukazují, jak používat strojové učení ve spojení s těmito modely, aby se dosáhlo kratší doby vývoje výrobních systémů.

$\checkmark$ rámci konceptu Industry 4.0 se začalo rozvíjet i téma prediktivní údržby. která má velký dopad na plánování a umožňuje plánovat výrobu s ohledem na prostoje, které budou způsobeny údržbou, poruchami apod. Tento přístup sleduje cíl eliminovat selhání systému dříve, než $\mathrm{k}$ němu dojde. Tím se zabrání stavưm. kdy zařízení vstoupí do neočekávaných prostojů a ušetří se vysoké náklady. Jedna z možnosti je využití generické prediktivní simulace údržby v nástroji AnyLogic ${ }^{\mathrm{TM}}$. Koncept obsahuje popis funkce a cíle simulace, rozhraní pro přenos dat do a ze simulace, obecnou strukturu simulace a ukazatele používané $\mathrm{k}$ vyhodnocení simulovaných plánů výroby. První př́ípadová studie ukazuje, jak Ize simulační model použít k simulaci vzorových dat $z$ testbedu pro zlepšení výrobních plánů [16]. Dle S. Teufl et al. [17] dnes není neobvyklé mít prediktivní model továrny i když tyto modely jsou často zjednodušené povahy. Takové modely však jen zřídka odrážejí aktuální provozní výkonnost systému, používají jednoduché a oddělené datové proudy a nemají rozlišení stroje / pracovní stanice. Mohou podporovat plánování výroby, ale obvykle mají omezené využití pro optimalizaci výkonu továrny $v$ reakci na měnící se vnější podněty. Proto výzkumný projekt OPTIMIZED vyvijí holistickou platformu pro řízení závodu, který reaguje na neočekávané poruchy v továrně. Představují aplikaci optimalizace založené na simulaci na podporu plánování výroby výrobního procesu jednoho z průmyslových demonstrantů. Simulační model zachycuje príslušná výrobní omezení továrny až na každý stroj a pracovní stanici. Simulační model čte data z podnikových informačních systémů, živá data ze strojů a data z dovybavených senzorů ve výrobním závodě. Výsledkem je, že dochází k optimalizaci úrovně služeb i výrobních nákladů.

Podle P. Fantini a spol. [18] že s ohledem na rozrůstající se cyber physical systémy existuje velká shoda $v$ tom, že se práce změní a budou nutné různé dovednosti. Otázkou však zůstává, zda se organizace práce bude vyvíjet směrem $k$ vyšší odpovědnosti a rozhodování zaměstnanců nebo $k$ vyšší technologické kontrole. Výzvou je tento vývoj řídit a cíleně vést proces integrace lidí do CPS. Autoři navrhují metodologii na podporu navrhování a hodnocení různých pracovních konfigurací a zvažují jedinečnost lidské práce a charakteristiky kybernetické výroby $v$ komplexním rámci. Metoda zahrnuje běžnou výrobu i nepravidelné scénáře, jako je detekce poruch nebo zásah údržby, zvláště zajímavý pro lidskou práci. Použitelnost této metody je ilustrována dvěma průmyslovými prípady, které vedou k návrhům na školení personálu a ke zlepšení celého kybernetického-sociálního-sociálního systému. Tento text $v$ rešerši uvádím jako zajímavou možnost, jak se dívat na simulaci jako nástroj pro rozhodování z pohledu osoby rozhodující co bude dělat stroj a co člověk. 
Simulace, popř. digitální dvojče se dnes běžně využívá i jako podklad pro rozhodování. Autoři B. Denkena a F. Winter [19] využívají simulaci výroby rotorových listů $v$ odvětví větrných turbín jako podklad pro rozhodování $\mathrm{s}$ cílem snížení doby plánování a nákladů, a aby se odhadl vzájemný dopad na výrobní kapacitu podle produktu, technologie a továrny $\mathrm{v}$ rámci plánovací fáze. Autoři W. Yang a S. Takakuwa [20] jdou ještě dále, a zaměřují se na plánování výroby sohledem na možnou probíhající komunikaci mezi výrobcem a zákazníkem. Výrobce je díky Industry 4.0 schopen rychleji reagovat na požadavky zákazníků, což znamená, že výrobci musí nyní pevněji kontrolovat plánování výroby. Do simulačního modelu se importuje objednávka zákazníka a tabulka zpracování produktů. Experimenty jsou implementovány pro prípad, kdy systém narazí na neočekávané podmínky. Navrhovaný přístup představuje pro výrobce potenciální nástroj pro rozhodování v reálném čase. C. L. Constantinescu a kol. [21] považují za jednou z hlavních výzev Industry 4.0 zajistit, aby správní lidé měli správné informace ve správný čas, aby mohli učinit správná rozhodnutí. Proto přichází $s$ víceúrovňovým simulačním nástrojem just-in-time pro podporu rozhodování v plánování digitálního závodu. Ten využívá vhodné prostředky pro zachycení a reprezentaci znalostí výrobního systému $v$ několika typech průmyslových odvětví a typů společností (velké, malé a střední podniky). Pro podporu modelovací činnosti, rozhraní člověk-systém simulačního nástroje využívá vyhledávání informací $v$ reálném čase (JITIR) pro proaktivní poskytování požadované informace ve správný čas na základě kontextu během modelování a simulace.

Možností, jak využít simulaci a vizualizaci pro rychlé ověření plánů výrobních toků je metoda generování poloautomatických modelů rízených daty [22], který je ilustrován na přikladu implementace pomocí simulačního software FexSim. A. Caggiano a R. Teti [23] využívají nástrojů digitálního modelování a simulace pro krátkodobou analýzu a validaci strategií řízení výroby, popř. pro střednědobé plánování výroby nebo návrh/redesign výrobního systému. Navrhují metodiku Digital Factory na podporu rozšírení stávající výrobní buňky pro výrobu lopatek turbín leteckých motorů pomocí robotické automatizace její odhrotovací stanice. K ověření upgradované výrobní buňky s cílem zvýšit její výkonnost $z$ hlediska využití zdrojů a doby průchodu, je využito 3D modelování a diskrétní simulace. Validace simulačního modelu se provádí sbíráním skutečných dat z fyzicky rekonfigurované výrobní buňky a jejich porovnáním s prognózou modelu.

V současné době chybí dle G. Avventuroso a kolektivu [24] znalosti a strukturované prístupy týkající se přechodu výrobních systémů z rychlého prototypování na velkovýrobu. Představují tedy postup pro simulační analýzu FMS podporující plánování, návrh a hodnocení výkonu. Vyvinuli a použili diskrétní simulační model pro provozní vyhodnocení průmyslového případu, který zahrnuje 3D-tisk, automatizovaný transport a skladovací systémy.

Dle autorů P. Goodall, R. Sharpe, a A. West [25] mohou ze simulací těžit obzvláště repasovací operace jako podpora posuzování různých strategií pro 
scénáře $v$ reálném čase kvůli nejisté povaze návratnosti produktu. Navrhují simulaci založenou na datech, která se skládá ze tří prvků:

1. adaptivní algoritmus remanufacturing simulace pro modelování komplexního materiálového toku nalezeného $v$ procesu remanufacturing obecným a opakovaně použitelným způsobem,

2. informační model pro strukturování a zvýraznění požadavky na simulační data

3. vrstvu informačních služeb pro shromažd’ování a analýzu dat senzorů pro použití v simulaci.

Simulace je implementována za účelem demonstrace toho, jak Ize automaticky překonfigurovat a přizpůsobit se změnám $v$ datových vstupech (procesní a tovární modely) pomocí prípadové studie operací od výrobce odpadu z elektrických a elektronických.

\section{Metodika př́stupu $k$ tvorbě simulačního modelu v kontextu Industry $\mathbf{4 . 0}$ a využití simulačních modelů}

Standardní prístup ve vytváření modelů a následných simulací je vytvoření modelu bez vrstvy, která by zajištovala komunikaci mezi jednotlivými stroji, popř. stroji a pracovníky na různých pozicích i různých hierarchických stupních. $\vee$ tuto chvíli se $v$ případě potřeby pokrytí rozhodování využívá standardních „if“ podmínek na daném vstupu/výstupu, popř. u přepravního systému (dopravník, vysokozdvižný vozík, roznos, ...). Otázkou tedy např. může být, zda tok materiálu/výrobku by mohl být vyhodnocovaný ne pouze podle následujícího pracoviště/úkonu, ale podle komplexního pohledu na stav výrobního úseku, haly, popř. celé továrny včetně odloučených pracovišt', nebo závodů. V článku "Industry 4.0 and the New Simulation Modelling Paradigm" [26]. Představují autoři vliv konceptu Industry 4.0 na vývoj nového paradigmatu simulace, ztělesněného konceptem Digital Twin. Hlavní poučení je, že zatímco nové paradigma simulačního modelování je přijímáno velkými společnostmi a malými a středními podniky, existují značné rozdíly $v$ závislosti na velikosti společnosti v problémech, jimž čelí, a používaných metodologiích a technologiích. Zatímco zkoumané príipady naznačují přijetí nového modelu simulačního modelování $v$ průmyslových a vědeckých komunitách, jeho přijetí v akademickém prostředí vyžaduje úzkou spolupráci s průmyslovými partnery a diverzifikaci znalostí výzkumných pracovníků, aby bylo možné vybudovat integrované, víceúrovňové modely kybernetických systémů. Jak ukazuji předložené případy, nedostatek nástrojů není problém, protože současná generace nástrojů pro modelování pomocí diskrétních simulací pro všeobecné použití nabízí adekvátní možnosti integrace.

Častým požadavkem při tvorbě simulačních modelů je možnost využívat je jako vzdělávací platformu, a to nejčastěji pro vzdělávání v simulacích, komunikaci, konceptu Industry 4.0 apod. Dle T. Delbrueggera a kol. [27] je simulace a digitální dvojče cestou jak $v$ malých a středních podnicích využít 
jejich potenciál. Přičemž autoři kladou důraz na propojení virtuálních a fyzických artefaktů. To následně inspiruje podniky ke změnám. Na nedostatek znalostí konceptu Industry 4.0 a možností simulací s možností automatizovaného sběru dat upozorňují i T. H. J. Uhlemann a kol. [28], kteří na digitálním dvojčeti $s$ využitím sběru dat $v$ reálném čase demonstrují výhody těchto řešení pro SME a považují jej za vhodnou vzdělávací platformu pro tuto velikost organizací. Na neznalost podniků upozorňují i D. Mourtiz a kol. [29], kteří se zaměřují na snahu propojit akademickou sféru ovládající simulace se soukromým sektorem, pro které to je užitečným, ale poměrně neznámým nástrojem. Teaching Factory považují za chybějící článek, jehož cílem je překlenout propast mezi akademickou obcí a průmyslem. Proto ukazují návrh a vyhodnocení skutečného výrobního systému pomocí diskrétní simulace a na základě reálných dat získaných z metalurgického průmyslu prezentováno $v$ kontextu paradigmatu Teaching Factory. Naopak S. Lang a kol. [30] představují koncept a současný stav vývoje modulární, decentralizované a digitální továrny na učení pro využití studenty a výzkumnými pracovníky. Kromě prezentace průmyslových modulů a jejich nastavení představuji rí́dicí a komunikační strategii, která umožňuje vytvoření a provoz libovolného preferovaného rozvržení $v$ podniku. Dále stručně popisují model diskrétní simulace a model emulace pro virtuální uvedení do provozu.

Dalším zajímavým trendem se ukazuje využití simulace a popř. digitálních dvojčat pro nastavení spolupráce výrobních podniků a popř. využívání kooperací. B. Kadar a kol. [31] navrhují využívat simulaci s cílem řídit sít' výrobců, kteři mohou dynamicky překonfigurovat a sdílet své zdroje $v$ rámci předregistrované komunity, a analyzovat, jak kardinalita takového „společenství" ovlivňuje jak spolupráci, tak globální a místní produkční KPI. Naopak T. Kaihara a kol. [32] představují Crowdsourced production, nový typ výroby, ve kterém společnosti sdílejí své výrobní zdroje v závislosti na jejich poptávce a kapacitě. Podle toho společnosti sdílejí své informace o zdrojích a mohou najít outsourcingovou společnost, když potřebují konkrétní/specifické zdroje. Autoři vyvinuli simulační model výroby s crowdsourcedem s modelem zdroje a vyjednávacím algoritmem založeným na agentech pro vyhodnocení efektivity výroby na základě dodávky a využití stroje. Podle kombinace a vyváženosti obchodního stylu se míra doručování mění s bodem nasycení, který závisí na shodnosti zdrojů. A. K. Turker a kol [33] pak využívají sběr dat $v$ reálném čas a simulace $\mathrm{k}$ rozhodování, zda při výrobě $v$ budoucnu dojde ke zpoždění nebo ne a navržený systém na základě toho rozhoduje o outsourcingu výroby zakázky.

Častým trendem využití simulace je i možnost nejen predikce potřebných oprav, popř. prostojů, ale i reorganizace a realizace jiného plánu výroby než standardního např. při nenadálé poruše [34]. $V$ takovém prípadě je problém předvídat možné poruchy, a hlavně mít připravené scénáře pro chování systému. Proto autoři článku navrhují metodiku pro získání znalostí o údržbě pomocí metody počítačové simulace. Předložený príklad vytvořili pomocí 
softwaru Tecnomatix Plant Simulation. Obdobnému tématu se věnuje i H.-J. Shin a kol. [35], kteří studují aktivní ochranu pro umožněni funkce „sebeopravy“. Autoři navrhli modelování dílny a dynamické rekonfigurovatelné schéma CPS, které může předpovídat výskyt anomálií a sebeochrany $v$ modelu. Za tímto účelem byla technologie strojového učení umožňující omezit přetížení ve výrobním procesu. Výsledkem je navržený simulační model autonomně detekující abnormální situace a je dynamicky rekonfigurovatelný pomocí sebeopravy.

V článcích zabývajících se simulací se pak ukazuje i další směr, kterým se simulace vydávají - propojování. Nejde jen o propojování s hardwarem, který např. umožňuje sběr dat $v$ reálném čase, ale $\mathrm{i}$ o propojení softwaru pro diskrétní simulace a softwarem pro simulaci dynamiky [36], kde autoři představují integrační mechanismus pro online komunikaci mezi těmito nástroji a navíc ji využívají pro ověření logiky naprogramovaného PLC. Jiným príkladem je propojení diskrétní simulace a virtuální reality (VR DES) [37]. Označují VR DES jako novou platformu pro testování scénáruu a rozhodování. V práci se řeší potřebné komunikační protokoly, aspekty návrhu systému, validace modelu a aplikace VR a DES. Dle autorů je potřeba další výzkum v oblastech zpracování obrazu s nižší latencí, dodávky DES jako služby, rozpoznávání gest pro VR Interakce DES a propojení DES $s$ datovými toky v reálném čase a soubory velkých dat. T. Delbruegger et al. [38] se pak zaměřují na propojování simulačních systémů. Podle autorů nelze simulační modely snadno kombinovat, a proto nelze interdisciplinárních globálních optimalizací často možné dosáhnout. Navíc aspekt lidské interakce s tak komplexními ko-simulačními systémy je často opomíjen. Proto představují koncept pro kombinaci různých simulačních modelů $s$ interdisciplinárními víceúrovňovými simulacemi produkčních systémů. Koncept zahrnuje tři hierarchické úrovně produkčních systémů (Process Simulation, Factory Simulation a Human Interaction) a umožňuje interakci člověka se simulačním systémem, koncept Ize ale snadno rozširíit, aby podporoval další úrovně. V rámci víceúrovňové struktury provádí každý simulační systém vícecílovou optimalizaci. Paretoptimální řešení jsou předávána simulacím na vyšších hierarchických úrovních, aby je mohla kombinovat a splnit flexibilně přizpůsobitelné cíle celého výrobního systému. Koncept je testován pomocí zjednodušeného výrobního systému, aby byl optimalizován z hlediska doby výkonu a spotřeby elektrické energie. Výsledky ukazují na potenciál takto optimalizovat produktivitu a efektivitu výrobních systémů.

Y. Lu a kolektiv [39] se zabývají nedávným vývojem technologií Digital Twin ve výrobních systémech a procesech, analyzují konotace, scénáře aplikací a výzkumné otázky inteligentní výroby Digital Twin-řízené výroby $v$ kontextu Industry 4.0. Ve své práci identifikují nevyřešené výzkumné problémy vývoje digitálních dvojčat pro inteligentní výrobu. Jsou to:

1. Standardizovat vzor architektury pro digitální dvojče ideální kombinací dvou aktuálně používaných architektur

2. Zaměřit se na snížení latence komunikace pro digitální dvojčata 
3. Standardizovat mechanismus sběru dat (definovat best practises)

4. Definovat standardy pro digitální Twin

5. Standardizovat/navrhnout výchozí funkce digitálního dvojče

6. Zaměřit se na správu verzí modelu Twin Twin

7. Zaměřit se na „simulování“ lidí v aplikacích Digital Twin

S. Kern a J. Scholz [40] se zabývají prístupem k simulaci založeným na modelování agentů pro vnitřní výrobní prostory. Simulační metody používají $k$ optimalizaci prostorové dimenze $s$ ohledem na simulaci výrobních procesů. Model založený na agentech vyvinutý v tomto článku je využíván $\mathrm{k}$ simulaci výrobního prostředí pomocí umělého vnitřního prostoru a sady testovacích dat. Výsledky ukazují, že různé úrovně dostupných prostorových informací mají vliv na výsledky simulace vnitřních výrobních prostředí a procesů. Vzdálenosti překonávané pracovními agenty mohou být významně sníženy stejně jako neproduktivní pohyby pracovních agentů (bez výrobních aktiv).

\section{$5 \quad$ Koncept Industry $\mathbf{5 . 0}$}

Pojem Industry 4.0 (též Průmysl 4.0, Práce 4.0, nebo čtvrtá průmyslová revoluce) označuje aktuální trend digitalizace a automatizace výroby včetně jejich dopadů na trh práce. Hlavní myšlenkou tohoto konceptu je vykonávání opakujících se a jednoduchých činností, které aktuálně vykonávají lidé, stroji. I když se o konceptu Industry 4.0 mluví hlavně v posledních necelých deseti letech, tak jde o využívání technologií, které jsou $v$ některých případech dostupné už např. od 90 . let 20 . století a do té doby se jen vyvíjejí, popř. upravují. Očekávaným nástupcem tohoto konceptu by měl být koncept Industry 5.0 (nebo Průmysl 5.0, Práce 5.0, pátá průmyslová revoluce apod.). Počty vědeckých článků operujících s pojmem „Industry 5.0“ je velmi nízký. V databázích WoS a Scopus se jedná o jednotky textů. Ve většině případů se navíc netýkají a nijak nedotýkají prủmyslu, ale např. zdravotnictví, nebo sociálních věd. Počty odborných, ale nevědeckých článků jsou podstatně vyšší a při využití vyhledávače je vidět, že jde o poměrně často diskutované téma, kterému se věnuje hodně nevědeckých autorů.

Ve vědeckých textech je koncept Industry 5.0 představován jako:

- Nadstavba aktuálního konceptu Industry 4.0 s ohledem na bezpečnost, kterou se koncept Industry 4.0 zabývá pouze okrajově i přesto, že staví na loT a inteligentní výrobě, popř. inteligentních továrnách. Extrémní automatizace, dokud „vše není spojeno se vším ostatním“, představuje zranitelná místa, která byla dosud jen velmi málo zvažována. [41]

- Propojení robotů s lidským mozkem. V tomto prípadě je vnímána nutnost zvýšit produktivitu, aniž by byli lidé z výrobního průmyslu vyloučeni. Abychom čelili těmto výzvám, zavádí autoři koncept Industry 5.0, kde jsou roboti propojeni s lidským mozkem a pracují 
jako spolupracovníci místo konkurence. Autoři argumentují, že takto pojatý koncept Industry 5.0 vytvoří více pracovních míst.[42]

- Následování prírody, tedy Bionika (imitace nebo abstrakce „vynálezư“ prírody). Chemický průmysl již používá tzv. „bílou biotechnologii“ pro nové procesy, suroviny a udržitelnější využívání zdrojủ. Syntetická biologie se také používá $\mathrm{k}$ vývoji biopaliv druhé generace a ke sběru sluneční energie pomocí mikroorganismů, nebo biometricky navržených katalyzátorů. Tržní potenciál bioniky $v$ medicíně, inženýrských procesech a ukládání DNA je obrovský. Projekty ve světě se již agresivně zaměřují např. na nemoci a nové materiály vytvořené touto cestou. Začátek konceptu Industry 5.0 by měl být dle autorů položen kódováním inženýrských projektů, umělou DNA, biologickými obvody apod. [43]

- Dalším krokem po dokončení digitalizace. Koncept Industry 5.0 by měl stát na spolupráci se zákazníky, orientaci na služby. obratnosti a zkušenosti při komunikaci se zákazníky a autoři tyto schopnosti považuji v konceptu Industry 5.0 za kritické. Firemní strategie se proto změní z konkurenční strategie na strategii spolupráce. Spolupráce se zákazníky by měla být prováděna prostřednictvím strategie společné tvorby (CCS) [44]. Hlavní myšlenkou tedy je využít zákazníka už při návrhu a výrobě produktu/služby.

Pohledy na koncept Industry 5.0 z vědeckých článků se z velké části shodují s pohledy objevujícími se vodborných, ale nevědeckých článcích, kde nejčastější pohled na koncept Industry 5.0 je hlavně ve velké individualizaci výrobků/služeb a spolupráce člověka s robotem (ústup od absolutní robotizace), viz např. článek „Trend Průmysl 5.0 k továrnám bez lidí nesměruje“, zveřejněný na www.vseoprumyslu.cz [45], nebo „Přichází Průmysl 5.0 zveřejněný na www.systemylogistiky.cz [46]. Tento trend by mohl potvrzovat i čím dál tím vyšší zájem o kolaborativní roboty jak u výrobních společností, tak společností poskytujících služby.

\section{Závěr}

Simulace a myšlenka digitálních dvojčat se i v konceptu Industry 4.0 ukazují je potřebný nástroj nejen pro plánování $s$ ohledem na různorodé požadavky jako např. minimalizace nákladů, zvýšení produktivity, „zelená“ výroba, ale např. i pro vzdělávání. Význam simulace a digitálních dvojčat v aktuálním vývoji stále nabývá na významu. Je pozorovatelný trend navíc simulace a digitální dvojčata rozšiřovat o nové technologie a možnosti, jako např. strojové učení, sběr dat v reálném čase, propojení s virtuální realitou, propojování diskrétní a simulace dynamiky, nebo např. propojování simulací a digitálních dvojčat napříč společnostmi za cílem zjednodušení kooperací a outsourcingu. Vliv detailnosti modelu na výsledky simulace se pak bere jako určitý fakt a výzkumy $v$ tomto směru $v$ obecné rovině neprobíhají. Naopak se podle všeho 
řeší detailnost modelu pro konkrétní projekt. Zobecnění $v$ tomto případě predstavuje pouze graf uvedený $v$ textu.

Naopak téma Industry 5.0 vyznívá $v$ tuto chvíli pouze jako marketingová záležitost než skutečné vědecké téma.

\section{Poděkování}

Tento článek byl vytvořen za podpory interního grantu Západočeské univerzity číslo projektu je SGS-2018-031 s názvem Optimalizace parametrů udržitelného výrobního systému.

\section{Použitá literatura}

[1] M. Dorda, „Úvod do modelování a simulace systémů", s. 46.

[2] P. Šenkýřr, „Využití simulačních metod pro podporu procesního řizení v systémech integrovaného managementu". 2011.

[3] V. Glombíková, „POČíTAČOVÁ SIMULACE PODNIKOVÝCH PROCESU゚. Ing. V. Glombíková, PhD." https://docplayer.cz/8986738-Pocitacovasimulace-podnikovych-procesu-ing-v-glombikova-phd.html (viděno bře. 24, 2020).

[4] S. Klos a J. Patalas-Maliszewska, „Simulation Modeling of Assembly Processes for Digital Manufacturing", in Advances in Manufacturing li, Vol 1 - Solutions for Industry 4.0, J. Trojanowska, O. Ciszak, J. M. Machado, a I. Pavlenko, Ed. Berlin: Springer-Verlag Berlin, 2019, s. 261-273.

[5] Z. Zhang, R. Tang, T. Peng, L. Tao, a S. Jia, „A method for minimizing the energy consumption of machining system: integration of process planning and scheduling", J. Clean Prod., roč. 137, s. 1647-1662, lis. 2016, doi: 10.1016/j.jclepro.2016.03.101.

[6] T. Wu, F. Xiao, C. Zhang, Y. He, a Z. Liang, "The green capacitated multiitem lot sizing problem with parallel machines", Comput. Oper. Res., roč. 98, s. 149-164, rijj. 2018, doi: 10.1016/j.cor.2018.05.024.

[7] A. Zandi, R. Ramezanian, a L. Monplaisir, "Green parallel machines scheduling problem: A bi-objective model and a heuristic algorithm to obtain Pareto frontier", J. Oper. Res. Soc., doi: 10.1080/01605682.2019.1595190.

[8] Q. Su, W. Yang, a Y. Liu, „Optimization of carbon emission considering production planning at enterprise level", J. Clean Prod., roč. 162, s. 635645, zár. 2017, doi: 10.1016/j.jclepro.2017.06.092.

[9] S.-J. Shin, S.-H. Suh, a I. Stroud, „A green productivity based process planning system for a machining process", Int. J. Prod. Res., roč. 53, č. 17, s. 5085-5105, záŕ. 2015, doi: 10.1080/00207543.2014.988884.

[10] N. Liu, Y. F. Zhang, a W. F. Lu, „Improving Energy Efficiency in Discrete Parts Manufacturing System Using an Ultra-Flexible Job Shop Scheduling Algorithm", Int. J. Precis Eng Manuf-Green Technol., roč. 6, č. 2, s. 349365, dub. 2019, doi: 10.1007/s40684-019-00055-y. 
[11] H. Junker a C. Domann, „Towards Industry 4.0 in Corporate Energy Management", in Ecosystems and Sustainable Development Xi, roč. 214, D. Almorza a C. A. Brebbia, Ed. Southampton: Wit Press, 2017, s. 49-56.

[12] A. Kruse, T. H.-J. Uhlemann, a R. Steinhilper, „Simulation-based assessment and optimization of the energy consumption in multi variant production", in 13th Global Conference on Sustainable Manufacturing Decoupling Growth from Resource Use, roč. 40, G. Seliger, H. Kohl, a J. Mallon, Ed. Amsterdam: Elsevier Science Bv, 2016, s. 396-401.

[13] L. Atorf a J. Rossmann, "Interactive Analysis and Visualization of Digital Twins in High-Dimensional State Spaces", in 2018 15th International Conference on Control, Automation, Robotics and Vision (icarcv), New York: leee, 2018, s. 241-246.

[14] T. H.-J. Uhlemann, C. Lehmann, a R. Steinhilper, „The Digital Twin: Realizing the Cyber-Physical Production System for Industry 4.0", in 24th Cirp Conference on Life Cycle Engineering, roč. 61, S. Takata, Y. Umeda, a S. Kondoh, Ed. Amsterdam: Elsevier Science Bv, 2017, s. 335-340.

[15] F. Jaensch, A. Csiszar, C. Scheifele, a A. Verl, Digital Twins of Manufacturing Systems as a Base for Machine Learning. New York: leee, 2018, s. 7-12.

[16] M. Zarte, U. Wunder, a A. Pechmann, „Concept and First Case Study for a Generic Predictive Maintenance Simulation in AnyLogic (TM)", in lecon 2017 - 43rd Annual Conference of the leee Industrial Electronics Society, New York: leee, 2017, s. 3372-3377.

[17] S. Teufl et al., „OPTIMISED - Developing a State of the Art System for Production Planning for Industry 4.0 in the Construction Industry Using Simulation - Based Optimisation", in Transdisciplinary Engineering Methods for Social Innovation of Industry 4.0, roč. 7, M. Peruzzini, M. Pellicciari, C. Bil, J. Stjepandic, a N. Wognum, Ed. Amsterdam: los Press, 2018, s. 731740.

[18] P. Fantini, M. Pinzone, a M. Taisch, „Placing the operator at the centre of Industry 4.0 design: Modelling and assessing human activities within cyberphysical systems", Comput. Ind. Eng., roč. 139, s. UNSP 105058, led. 2020, doi: 10.1016/j.cie.2018.01.025.

[19] B. Denkena a F. Winter, „Simulation-based planning of production capacity through integrative roadmapping in the wind turbine industry", in 9th Cirp Conference on Intelligent Computation in Manufacturing Engineering - Cirp Icme '14, roč. 33, R. Teti, Ed. Amsterdam: Elsevier Science Bv, 2015, s. 105-110.

[20] W. Yang a S. Takakuwa, „Simulation-Based Dynamic Shop Floor Scheduling for a Flexible Manufacturing System in the Industry 4.0 Environment", in 2017 Winter Simulation Conference (wsc), V. Chan, A. DAmbrogio, G. Zacharewicz, a N. Mustafee, Ed. New York: leee, 2017, s. 3908-3916.

[21] C. L. Constantinescu, E. Francalanza, a D. Matarazzo, „Towards knowledge capturing and innovative human-system interface in an open-source factory modelling and simulation environment", in 9th Cirp Conference on Intelligent 
Computation in Manufacturing Engineering - Cirp Icme '14, roč. 33, R. Teti, Ed. Amsterdam: Elsevier Science Bv, 2015, s. 23-28.

[22] D. Krenczyk, W. M. Kempa, K. Kalinowski, C. Grabowik, a I. Paprocka, "Integration of manufacturing operations management tools and discrete event simulation", in Modtech International Conference - Modern Technologies in Industrial Engineering Vi (modtech 2018), roč. 400, E. Oanta, M. Naito, C. Carausu, P. Topala, M. Placzek, C. Schnakovszky, V. Paunoiu, V. Cohal, a D. Nedelcu, Ed. Bristol: lop Publishing Ltd, 2018, s. 022037.

[23] A. Caggiano a R. Teti, „Digital factory technologies for robotic automation and enhanced manufacturing cell design", Cogent Eng., roč. 5, č. 1, s. UNSP 1426676, led. 2018, doi: 10.1080/23311916.2018.1426676.

[24] G. Avventuroso, R. Foresti, M. Silvestri, a E. M. Frazzon, „Production Paradigms for Additive Manufacturing Systems: a Simulation-based Analysis", in 2017 International Conference on Engineering, Technology and Innovation (ice/ltmc), R. JardimGoncalves, J. P. Mendonca, M. Pallot, A. Zarli, J. Martins, a M. Marques, Ed. New York: leee, 2017, s. 973-981.

[25] P. Goodall, R. Sharpe, a A. West, „A data-driven simulation to support remanufacturing operations", Comput. Ind., roč. 105, s. 48-60, úno. 2019, doi: 10.1016/j.compind.2018.11.001.

[26] B. Rodic, "Industry 4.0 and the New Simulation Modelling Paradigm", Organizacija, roč. 50, č. 3, s. 193-207, srp. 2017, doi: 10.1515/orga-20170017.

[27] D. Grube, A. A. Malik, a A. Bilberg, „SMEs can touch Industry 4.0 in the Smart Learning Factory", in Research. Experience. Education., roč. 31, C. Herrmann a S. Thiede, Ed. Amsterdam: Elsevier Science Bv, 2019, s. 219224.

[28] T. H.-J. Uhlemann, C. Schock, C. Lehmann, S. Freiberger, a R. Steinhilper, "The Digital Twin: Demonstrating the potential of real time data acquisition in production systems", in 7th Conference on Learning Factories (clf 2017), roč. 9, J. Metternich a R. Glass, Ed. Amsterdam: Elsevier Science Bv, 2017, s. $113-120$.

[29] D. Mourtzis, A. Vasilakopoulos, E. Zervas, a N. Boli, „Manufacturing System Design using Simulation in Metal Industry towards Education 4.0", in Research. Experience. Education., roč. 31, C. Herrmann a S. Thiede, Ed. Amsterdam: Elsevier Science Bv, 2019, s. 155-161.

[30] S. Lang, T. Reggelin, M. Jobran, a W. Hofmann, „Torwards a Modular, Decentralized and Digital Industry 4.0 Learning Factory", in 2018 Sixth International Conference on Enterprise Systems (es 2018), New York: leee, 2018, s. 123-128.

[31] B. Kadar, P. Egri, G. Pedone, a T. Chida, „Smart, simulation-based resource sharing in federated production networks", CIRP Ann-Manuf. Technol., roč. 67, č. 1, s. 503-506, 2018, doi: 10.1016/j.cirp.2018.04.046.

[32] T. Kaihara, Y. Katsumura, Y. Suginishi, a B. Kadar, „Simulation model study for manufacturing effectiveness evaluation in crowdsourced manufacturing", 
CIRP Ann-Manuf. Technol., roč. 66, č. 1, s. 445-448, 2017, doi: 10.1016/j.cirp.2017.04.094.

[33] A. K. Turker, A. Golec, A. Aktepe, S. Ersoz, M. Ipek, a G. Cagil, „A real-time system design using data mining for estimation of delayed orders an application", J. Fac. Eng. Archit. Gazi Univ., roč. 35, č. 2, s. 709-724, 2020, doi: $10.17341 /$ gazimmfd.478648.

[34] S. Klos, „Knowledge Acquisition Using Computer Simulation of a Manufacturing System for Preventive Maintenance", in Information and Software Technologies, Icist 2018, roč. 920, R. Damasevicius a G. Vasiljeviene, Ed. Berlin: Springer-Verlag Berlin, 2018, s. 29-40.

[35] H.-J. Shin, K.-W. Cho, a C.-H. Oh, „SVM-Based Dynamic Reconfiguration CPS for Manufacturing System in Industry 4.0", Wirel. Commun. Mob. Comput., s. 5795037, 2018, doi: 10.1155/2018/5795037.

[36] Q. M. Goncalves Laurindo, T. A. Peixoto, a J. J. de Assis Rangel, "Communication mechanism of the discrete event simulation and the mechanical project softwares for manufacturing systems", J. Comput. Des. Eng., roč. 6, č. 1, s. 70-80, led. 2019, doi: 10.1016/j.jcde.2018.02.005.

[37] C. J. Turner, W. Hutabarat, J. Oyekan, a A. Tiwari, „Discrete Event Simulation and Virtual Reality Use in Industry: New Opportunities and Future Trends", IEEE T. Hum.-Mach. Syst., roč. 46, č. 6, s. 882-894, pro. 2016, doi: 10.1109/THMS.2016.2596099.

[38] T. Delbruegger et al., "Multi-level simulation concept for multidisciplinary analysis and optimization of production systems", Int. J. Adv. Manuf. Technol., roč. 103, č. 9-12, s. 3993-4012, srp. 2019, doi: 10.1007/s00170019-03722-1.

[39] Y. Lu, C. Liu, K. I.-K. Wang, H. Huang, a X. Xu, „Digital Twin-driven smart manufacturing: Connotation, reference model, applications and research issues", Robot. Comput.-Integr. Manuf., roč. 61, s. 101837, úno. 2020, doi: 10.1016/j.rcim.2019.101837.

[40] S. Kern a J. Scholz, „Agent-Based Simulation for Indoor Manufacturing Environments-Evaluating the Effects of Spatialization", in Geospatial Technologies for Local and Regional Development, P. Kyriakidis, D. Hadjimitsis, D. Skarlatos, a A. Mansourian, Ed. Cham: Springer International Publishing Ag, 2020, s. 309-324.

[41] V. Özdemir a N. Hekim, „Birth of Industry 5.0: Making Sense of Big Data with Artificial Intelligence, ,the Internet of Things' and Next-Generation Technology Policy", OMICS A Journal of Integrative Biology, roč. 22, č. 1, s. 65-76, 2018, doi: 10.1089/omi.2017.0194.

[42] S. Nahavandi, "Industry 5.0-a human-centric solution", Sustainability (Switzerland), roč. 11, č. 16, 2019, doi: 10.3390/su11164371.

[43] P. Sachsenmeier, "Industry 5.0-The Relevance and Implications of Bionics and Synthetic Biology", Engineering, roč. 2, č. 2, s. 225-229, čer. 2016, doi: 10.1016/J.ENG.2016.02.015.

[44] L. W. W. Mihardjo, F. A. Sasmoko, a Elidjen, „Towards co-creation strategy and organizational agility based on customer experience orientation to 
shape transformational performance", International Journal of Innovation, Creativity and Change, roč. 6, č. 1, s. 236-248, 2019.

[45] U. Robots, „Trend Průmysl 5.0 k továrnám bez lidí nesměřuje", Vše o průmyslu. https://www.vseoprumyslu.cz/robotizace/kooperativniroboty/trend-prumysl-5-0-k-tovarnam-bez-lidi-nesmeruje.html (viděno bře. 23, 2020).

[46] „GLOSA: „Přichází Průmys| 5.0?«", Systémy Logistiky CZ, bře. 29, 2018. https://www.systemylogistiky.cz/2018/03/29/glosa-prichazi-prumysl-5-0/ (viděno bře. 23,2020 ). 